\title{
Enrichment of Electricigenic Biofilm for Synchronized Generation of Electric Current and Waste Water Treatment in Microbial Fuel Cells
}

\author{
Zargona Zafar, Kamran Ayaz, Iqra Sharafat, Shabeena Shah, Sarwat naz zafar, Naeem Ali* \\ Department of Microbiology, Quaid-i-Azam University, Islamabad, Pakistan \\ *E-mail: naeemali95@gmail.com, naeemali2611@gmail.com, naeemali@ qau.edu
}

doi: $10.20964 / 2018.05 .02$

Received: 16 January 2017 / Accepted: 22 January 2018 / Published: 10 April 2018

\begin{abstract}
Enrichment of electricigens was carried out in double chamber Microbial fuel cells (MFCs) for synchronized organic waste treatment and bioenergy recovery. Activated sludge was inoculated in MFCs to measure the effect of two carbon sources (sucrose and acetate) on current output. MFCs operated with sucrose showed current generation of $5 \mu \mathrm{A}$ and $3 \mu \mathrm{A}$ with COD removal efficiency $(86.04 \%$ and $77.85 \%)$ in two respective stages of enrichment. Whereas, the relative efficiency of MFCs run with acetate remained considerably low in the $1^{\text {st }}$ stage though it inclined to $4 \mu \mathrm{A}$ with $81.17 \%$ removal of COD after $2^{\text {nd }}$ stage of enrichment. Culture based analysis of anodic biofilms indicated the presence of different bacterial species i.e. Pseudomonas sp., Proteus sp., Citrobacter sp., with different biofilm forming capabilities (strong 5\%, moderate 15\% and weak 14.8\%) in sucrose and acetate fed MFCs. 454 pyrosequencing of acetate-fed MFC indicated clear difference between established biofilm communities on anode and sludge sample. Anodic biofilm was covered with both culturable and un-culturable Pseudomonas species along with Nitrosomonas europaea and Massilia sp., etc. Principle component analysis also confirmed that major contributing classes were $\alpha$ proteobacteria $(48.51 \%), \beta$-proteobacteria $(31.48 \%)$ and $\gamma$-proteobacteria $(16.16 \%)$. The results of current study implied that enrichment technique resulted in better selection of electricigens along with waste water treatment.
\end{abstract}

Keywords: Microbial fuel cells; Enrichment; Biofilm; Current; Pyrosequencing

\section{$\underline{\text { FULL TEXT }}$}

(C) 2018 The Authors. Published by ESG (www.electrochemsci.org). This article is an open access article distributed under the terms and conditions of the Creative Commons Attribution license (http://creativecommons.org/licenses/by/4.0/). 